\title{
The Structural Violence of Indigenous Suicide Prevention Policies in Canada
}

\author{
Bryce Anderson
}

\begin{abstract}
Aвstract: Indigenous peoples in Canada suffer from very high suicide rates of which there are various state-created programmes and efforts to combat. However, the variety of these programmes may be limited in their conceptions of Indigenous suicide. I predicted that by analysing existing suicide prevention policies and frameworks, I would find that they systematically place Indigenous peoples in vulnerable positions through the enforcement of Western ideals of health and suicide, thus providing inadequate support towards preventing suicide. This would constitute structural violence. I used a content analysis to analyse and code themes in suicide prevention policies in Canada. I found that suicide prevention policies perpetuate structural violence as these policies overwhelmingly conceive suicide as an outcome of poor mental health, based on colonial knowledge, which is economically self-serving to the state.
\end{abstract}

KeYwords: Canada, Indigenous, state, structural violence, suicide, suicide prevention policy

Indigenous peoples in Canada suffer from relatively high suicide rates, approximately three times that of the total Canadian rate (Carstens 2000; Henry et al. 2018; Powell and Gabel 2018). Various state-created programmes and efforts to reduce these rates have been put forth by the Canadian government. However, the variety of these programmes may be limited in their conceptions of Indigenous suicide. In other words, as suicide is often not a homogenously understood concept between two different people, any efforts to prevent it need to embrace its contextuality. Suicide and its meaning are contextual, and a onesize-fits-all approach cannot inform its prevention. However, if Canadian state-run prevention policies fail to acknowledge this, the status quo will not change. Such homogeneity in policies constitute present colonial actions, manifesting structural violence.

Following Seth Holmes (2013:43), I define structural violence as the violence committed by configurations of social inequalities that have injurious effects on bodies similar to the violence of a stabbing or shooting. In this case, I argue that suicide prevention policies and programmes that are explicitly built upon colonial settler logic, thus predicated on social inequalities, have injurious effects on Indigenous bodies as these programmes blatantly deprivilege Indigenous knowledge. Simultaneously and certainly not by accident, the colonial and settler logic that is promoted through these policies minimises the fault of the Canadian government in contributing to suicide.

The associated goal of this article is to grasp how the Canadian state conceptualises and provides support for Indigenous suicide. Scholars have argued that policies are effective instruments of power for shaping individuals (Shore and Wright 2005), or reforming people to new norms (Hyatt 2005). Thus, they are forms of biopower that allow the state to manage the population (Foucault 2004), especially citizens that it deems 'disorderly' (Scheper-Hughes 1992). Yves Engler (2016) writes that Canadian policymaking has typically been motivated by strategic thinking, rather than compassion (c.f. Lane 1999). Therefore, I argue that existing suicide prevention policies play an important role for the state: to shape, categorise, and mould Indigenous peoples' suicides into a general homogeneous understanding of suicide. This is in contrast to policies that engage with more development and inclusion of Indigenous knowledge and healing practice to be included in un- 
derstandings of suicide, prevention, and subsequent support from the state.

This article aims to survey the current landscape of Indigenous suicide policies in Canada. I hypothesise that these policies will fall short of representing anything other than Western ${ }^{1}$ and colonial settler ideals ${ }^{2}$ of health and suicide, thus providing inadequate support towards preventing suicide. This enforcement of ruling class ideals on the subordinate (Holmes 2013) consequently results in minimally effective suicide prevention or suicide prevention policies that certainly could be more nuanced and tailored to Indigenous conceptions of health.

\section{Study Design}

The data for this study is collected as part of a larger content analysis on media and policy depictions of Indigenous suicide in Canada (Anderson 2020). The primary aim of this specific article was to collect data that would represent the Canadian state's conceptualisation of and actions towards Indigenous suicide. While the 'Canadian state' is a broad concept, I must use such a term that is wide enough to include the different networks of actors (Latour 1984) that write these policies. For example, the actors behind the creation of a federal programme are not the same people who write a provincial programme. Likewise, 'Health Canada' is responsible for some of the material that I included, while other material was written by members of the Canadian senate. Thus, my definition of the 'Canadian state' represents any person, or network of actors, with the power to release frameworks on preventing suicide under the name or sponsorship of a provincial or the federal government. While this extends to hundreds if not thousands of people, the aim here is to gain an outlook of the types of suicide frameworks that the Canadian government in some way advocates for, promotes, and supports.

Therefore, any materials that were included in this section were developed by some extension of the federal Canadian state itself, or a provincial government. This facilitated the gathering of extra sources that, similar to a suicide prevention programme, would represent how the state conceives and deals with Indigenous suicide. Statutes, such as An Act Respecting a Federal Framework for Suicide Prevention, give recommendations of how to understand Indigenous suicide, and therefore fits this article's criterion.

Twenty-two materials ${ }^{3}$ were included in this suicide prevention policy analysis. A Google search was used to find these materials by querying 'Indigenous suicide Canada'. The search was therefore random, as I was not sure of which provinces would have their own policies and what federal documents I would find. Items that were excluded were news articles and opinion pieces since these are not policy materials but show up in searches for policies.

Most suicide prevention policies were written by provincial governments; provinces that had their own frameworks were Alberta, Nunavut, Manitoba, New Brunswick, Nova Scotia, and Saskatchewan. Some other provinces, such as Newfoundland and Labrador, sponsor third-party frameworks for their suicide prevention frameworks. For example, Roots of Hope is a multi-sited project that aims to reduce the impacts of suicide that is embraced by Newfound \& Labrador, New Brunswick, Saskatchewan, Alberta, and Ontario. Although these types of documents were not written by the governments, they developed in conjunction with government officials and were accepted as an official conceptual framework of suicide. Therefore, third-party suicide prevention plans that were endorsed and developed by provincial or federal governments were included.

Some reports and programmes in my sample were either not specifically about Indigenous suicide or not specifically about suicide. For example, New Brunswick's suicide prevention plan does not mention Indigenous suicide specifically, while Nova Scotia's plan has only a small section devoted within its larger suicide prevention framework to Indigenous suicide. Other documents, such as the Truth and Reconciliation commission's report, is not specifically about suicide but does make recommendations and references to Indigenous suicide. These were all included. For programmes not specifically about Indigenous suicide, the entire document was still included in the sample total. This is because the complete lack of mentioning Indigenous peoples or their suicides, in other words the erasure of people, is colonialism itself.

Following a common method in content analysis (Bernard et al. 2017; Bernard 2018), I came up with themes and codes to search for beforehand. These codes would allow me to find consistent themes across these documents, revealing the most common details that are consistently part of suicide prevention frameworks. I also made themes to be reliably identifiable. For example, while I did not have another coder other than myself, I assumed that it would be feasible for a coder to identify if the policy or report is alluding to past effects or ongoing effects of colonialism, as the documents often contextualised these descriptions as something historical or present. Ensuring that codes are easily identifiable and trying 
to take away as much of my own interpretation as possible contributes a small but salient basis of intercoder reliability (Bernard et al. 2017; Bernard 2018). Admittedly, intercoder reliability is impossible to completely ensure without actually having separate coders.

The categories themselves are useful in summarising where policies take aim and prioritise improvement to suicide prevention. 'Abnormal Mental Health Improvement' is a general term that refers to the policies that relate Indigenous suicide to those who are in an abnormal state of mind and are suffering from abnormal mental health. Recording the frequency of this (100 percent) is useful because it demonstrates that while every policy positions abnormal mental health as a main factor in Indigenous suicide, conceptions that constitute other categories-Change Racism or Discrimination (23 percent), Culturally Appropriate Prevention Services (50 percent), LongTerm Funding (27 percent), Ongoing Colonialism (18 percent), and Past Effects of Colonialism (45 percent)-are much less frequent. In other words, abnormal mental health is consistently recognised by policies and so are social determinants and risk factors (95 percent), but these are general categories that could apply to any suicidal person. All other categories just mentioned can be specifically tied to Indigenous peoples (and some others, i.e., low income-long-term funding, reduce racism and discrimination among other groups). By demonstrating the frequency of these categories, I can illustrate the general thinking of Canadian suicide policies: broad suicide prevention and conceptions being consistently applied to Indigenous suicide; nuanced and context-specific factors not so much.

Below is the full list of categories, along with their frequencies:
By identifying themes and suggested actions in policy, I was able to depict an associated picture of how federal and provincial governments conceptualise and address Indigenous suicide. Furthermore, I was also able to identify which themes or aspects did not show up often in policies compared to what I, or other scholars, hypothesised.

\section{Results}

\section{Mental Health, Social Determinants, and Structural Violence}

Jeffrey Ansloos (2018) calls for the importance of moving beyond a one-size-fits-all suicide prevention approach, as efforts must be founded on the social and material concerns of Indigenous communities, while being ecological, contextually reflective, structurally attuned, and politically active. However, I found quite the opposite within Canadian suicide prevention policies. Mental health paradigms reigned supreme in data, appearing in all (100 percent) of the policies that were examined. Furthermore, social determinant approaches dominated as the bases of suicide prevention ideologies, as almost all policies (95 percent) relied on this framework. Poor mental health was conceived as a social determinant in policies, as it is implied that having a vulnerable state of mental wellness is a risk factor to suicide.

The referenced 'mental health' paradigms are developed from Western psychology, or in other words, biomedical versions of health, which scholars have criticised for being assumed to be universally appropriate for Indigenous peoples (Gone 2009; Nelson and Wilson 2017). Ansloos (2017) writes that despite efforts from the Canadian government to integrate culturally grounded approaches into mental health

Table 1: Policy-Suggested Actions to Be Taken to Reduce Indigenous Suicide Rates

\begin{tabular}{lll}
\hline Theme/ Code Name & $\begin{array}{l}\text { \# of materials that } \\
\text { referenced theme (n= 22) }\end{array}$ & $\begin{array}{l}\text { Percentage of Materials } \\
\text { that Referenced }\end{array}$ \\
\hline Abnormal Mental Health Improvement & 22 & $100 \%$ \\
Change Racism or Discrimination & 5 & $23 \%$ \\
Culturally Appropriate Prevention Services & 11 & $50 \%$ \\
$\begin{array}{l}\text { Long-term Community Programme Funding and Resources } \\
\text { (i.e., more Indigenous counsellors) }\end{array}$ & 6 & $27 \%$ \\
Ongoing Colonialism recognition & 4 & $18 \%$ \\
Past Effects of Colonialism recognition & 10 & $45 \%$ \\
Social Determinants and Risk Factors reduction & 21 & $95 \%$
\end{tabular}

Source: (Anderson 2020) 
services, the efforts have failed to consider how Indigenous knowledge may be epistemologically dissonant with mental health paradigms. Indeed, while a number of policies (50 percent) made efforts to mention how services should be culturally appropriate, they did not adequately convey ideological differences of well-being and personhood.

Tailoring Western-made, biomedically informed understandings of mental health to Indigenous people, and subsequently deeming them culturally appropriate, is an example of a rather shallow attempt at achieving cultural appropriateness. For example, policies often reference developing programmes that are 'culturally appropriate' $4,5,6$. The literal term of "culturally appropriate" itself shows up in 59 percent of the policies examined. Consider the following quote from the Saskatchewan's First Nations Suicide Prevention Strategy (2018): 'We will strengthen the continuum of culturally appropriate mental health services (1)'. It is inherently contradictory to facilitate culturally appropriate support within a predetermined field that may not be culturally appropriate in the first place.

Meanwhile, the theme of 'Past Colonialism' showed up in 45 percent of the programmes. It seems that most of the frameworks about Indigenous suicide are aware of the detrimental effects that colonialism has had on Indigenous peoples' lives, rather than acknowledging that it is colonialism itself that is presently affecting Indigenous peoples. For example:

- 'Hundreds of years of colonization disrupted multiple generations of families, and have had lasting and profound effects on communities' (House of Commons 2017: 7).

- 'The experience of many youth is steeped in cultural disintegration, the breakdown of family structures, dislocation from the land, and economic and educational disadvantages due to the intergenerational impacts of colonization'(National Aboriginal Youth Suicide Prevention Strategy Framework 2019: 6).

- 'The elevated rate of suicidal behavior in First Nations is, in part, a legacy of colonial experiences and practices (including, but not limited to, intergenerational trauma and gendered violence resulting from Indian Residential Schools)' (Saskatchewan First Nations Suicide Prevention Strategy 2018: 33).

- 'The lasting impacts of these experiences include: marginalization; a loss of culture, community and family stability; as well as mental health and substance abuse issues, which can contribute to an individual's risk of suicide'(The
Federal Framework for Suicide Prevention 2016: 20).

As such, (50 percent) of materials referenced the need for services to be culturally appropriate; this was often justified by the programmes acknowledging that Indigenous peoples have different social determinants of suicide because of their pasts of colonialism. Therefore, policies and efforts are tailored to address colonialism and its effects on health. However, is it adequate to tailor the colonial approach that is mental health services itself to be culturally appropriate? Aside from the fact that this groups together Indigenous peoples under a seemingly unified experience of past colonialism, culturally appropriate mental health services within a colonial framework are not an alternative that addresses the particularity of suicide.

Furthermore, Sarah Nelson and Kathi Wilson (2017) suggest that a dichotomy may emerge when adding cultural appropriateness to mental health services. By integrating Western services with Indigenous ways of healing, Indigenous worldviews and Western perspectives are dichotomised, thus reinforcing stereotypical views rooted in colonialism. More specifically, the same study reviews media articles and concludes that these media representations often sharply distinguish between Indigenous ways of knowing and healing and Western/biomedical mental health services. Not only does this collapse both Indigenous and Western worldviews into homogeneous generalisations (Nelson and Wilson 2017), but it may relegate Indigenous knowledge to a peripheral position as perspectives that seem to be outside the realm of 'real science'.

Echoing James Staples (2016), people actively draw on embodied knowledge that influences how they act in a particular situation, and these unconscious perspectives are shaped by socialisation with a particular web of cultural circumstances. It suffices to say that Indigenous people and non-Indigenous people have different embodied knowledges and realities, as may any two Indigenous peoples, which may be influenced by their respective material conditions, histories, and experiences of ascription by state governance and different reactions to the material world (Macklem 1991; Murphy 2011). I argue that this embodied or cultural knowledge is related to health outcomes such as suicide. Similarly, Lisa M. Wexler and Joseph P. Gone (2016) write that cultural understandings construct parameters around sick and healthy roles, consequently structuring the most appropriate remedies. As health-related outcomes are not simply biological or psychological events, we 
must consider health along with socio-cultural factors (Leenaars 2006). However, cultural perspectives in suicidology are rarely seen, are underdeveloped, and are without an integration of multidisciplinary approaches (Kral 2012). Similarly, I cannot claim that the perspectives put forth in the policies that I examined in this section provide cultural perspectives on suicidology. In fact, I found quite the opposite.

This may present many problems for Indigenous peoples seeking support for suicide. I contend that it is extremely important for cultural perspectives to be developed not just for suicide but for other health areas as well. For example, programmes based on Western medicine and models have been found to be widely rejected by people living on the reservations (Kral 2012). While it is undoubtedly the case that many Indigenous peoples in Canada have benefited from such Western medicine and mental health, and I am almost positive (although it is beyond the scope of this article) that Western mental health counselling and frameworks have a reducing effect on Indigenous suicide rates, I humbly suggest that the embracement of alternatives by state programmes, including cultural knowledge, may increase the effectiveness of such suicide prevention efforts.

\section{Structural Violence}

Quite literally, structural factors are not a part of the discussion when the Canadian government conceives Indigenous suicide. Due to state-driven policies' overwhelming reliance on mental health being the cause for suicide, Indigenous suicide was not often referenced in regard to structural factors. This is representative of how Indigenous mental health is conceived; if poor mental health is not seen to be related to structural issues, suicide becomes individualised or medicalised (Targum and Kitanaka 2012). This locates the site of suicide, and ill-health for that matter, within the nature of the Indigenous person rather than in colonial actions (Henry et al. 2018), allowing the state to evade responsibility for the consequences.

The actual word 'structural' was only used in two pieces (9 percent) in reference to suicide in a separate word frequency test (Anderson 2020). This is problematic, and scholars have criticised falling short of accounting for structural factors. For example, writing about suicide in reference to reserves, Peter Carstens (2000) posits that psychological problems have their roots in social problems associated with the outside world. Nelson and Wilson (2017) write that while trauma is helpful in understanding the impacts of colonialism, it is important to remember that the processes are collective and structural forces, requiring collective and structural change, rather than pathological or individual change. Finally, psychological training, skill building, suicide awareness, and counselling are all useful tools to many people but are limited in their ability to change broader historical and current sociopolitical contexts of structural inequality that often provide the conditions for disconnection, depression, hopelessness, and worthlessness to take root and grow (White 2017).

Structural violence goes a layer deeper than simply not explicitly recognising the potential structural causes of suicide. Not only are mental health services and social determinants unable to situate suicide within larger, structural processes, they also fall short in making changes to overarching contributing factors to suicide, such as ineffective suicide prevention programmes and damaging media depictions. On this point, a quote from Michel Foucault comes to mind:

The real political task ... is to criticize the working of institutions that appear to be both neutral and independent; to criticize them in such a manner that the political violence which has always exercised itself obscure lie through them will be unmasked so that one can fight them. (Chomsky and Foucault 2006: 41)

I believe that the Canadian state is not neutral nor independent in its perpetuation of mental health promotion and services for Indigenous peoples. It is in the best interest of the state to use these frameworks in relation to Indigenous suicide. Allow me to be clear: any efforts made towards reducing and preventing suicide are ultimately positive. However, current forms of colonialism, such as the absolute enforcement of Western ideals about mental health from the colonial state upon Indigenous peoples, are rendered invisible due to the general sentiment and portrayal that colonialism is a finished project. Therefore, the state is seen only as benevolent in its efforts to implement mental health services and provide resources.

Policies are made to 'look good' but do not sufficiently address larger structural issues as they operate within a capitalist state governed by elites and their cadres of ideological supporters. The Canadian state actively maintains its benevolent image, thus diverting blame for Indigenous suicide away from its colonial past and present. Furthermore, like a corporation, the Canadian state displays a surface level support towards cultural sensitivity; Engler (2016) writes that this is often done to 'obfuscate their (ruling) classconscious politics and profit-oriented objectives' (140).

Take, for example, racism. In a word frequency test (Anderson 2020), the word 'racism', was used in 
eight (36 percent) of the policy documents, while five (23 percent) included racism as something to be changed in order to reduce suicide rates for Indigenous peoples. Interestingly, out of the eight materials that mentioned the word racism, four (50 percent) mentioned racism as a social determinant or risk factor to suicide. Racism is therefore relegated to being a social determinant of suicide. Notably, although racism may be listed on more than half the sample as a risk factor, dealing with the problem through systemic change is not part of the programming. This implies that the Canadian state conceives racism as a contributing factor to suicide, but it does not take responsibility for perpetuating it. The state's logic here is: 'if an Indigenous person experiences racism, they may be more likely to commit suicide, so we will deliver appropriate mental health services to convince these people not to commit suicide'; this is in lieu of the logic being: 'racism is a contributing factor to suicide, so we will make efforts to prevent racism in society, such as close monitoring of media or training healthcare professionals, to not perpetuate discrimination, so that people do not experience racism in the first place'.

There is a certain structural violence that occurs in this case wherein the Canadian state creates friction, for example, through upholding the Indian Act, which is a longstanding form of institutional racism and does not provide an accessible solution to it. This, in the case of Indigenous suicide and mental health services, may be understood in relation to capitalism and the market economy. Allow me to qualify this with two studies that similarly situate structural violence towards a minority group in a market setting.

Making these suicide prevention programmes and policies is an active process by the Canadian state. The decision to not change structural factors, to minimise the importance of context-specific factors such as racism and discrimination is proactive, rather than the Canadian government simply being at fault for not concluding structural factors. Structural violence is a method of violence in which the victim's agency is actively suppressed on a structural level (Farmer 2005; Holmes 2013). In the following section, I will situate this active structural violence in the associated literature.

\section{Infinite Insufficiencies}

In his study situated in the United States, Holmes (2013) argues that Mexican farm workers experience structural violence that is related to the growth of the free market. More specifically, Holmes writes that trade agreements and the corporatisation of agriculture directly limit a farm's ability to increase the pay of growers, or to improve labour camps without bankrupting the farm:

In other words, many of the most powerful inputs into the suffering of farm workers are structural, not willed by individual agents. In this case, structural violence is enacted by market rule and later channeled by international and domestic racism, classism, sexism, and anti-immigrant prejudice. (Holmes 2013: 52)

In the case of my study, I argue that locating the suicidal behaviour of Indigenous peoples within a biomedical mental health paradigm is stipulating that suicide is an individual act. The private sector, with active subsidies from the state, conceives populations merely as aggregations of individuals, glossing over social and economic contexts of poor health (Qadeer 2013; Rao 2009). While suicide prevention policies contend that decades of colonialism and oppression contribute to having poor mental health, more salient in policies are risk factors. These were prevalent in almost every policy (95 percent) that I examined and were presented as characteristics of individuals that may result in suicide. At the core of the explanation for suicide, these programmes see the individual's mental health as the ultimate and most salient contributor to suicide. Returning to Holmes' (2013) quote, powerful inputs are not willed by individual agents. Similarly, the Indigenous person is not able to control the inputs, yet they are supposedly at the centre of their own mental health and suicide. Rather, the private sector, with its own priorities for investments, such as technologies and more profitable ventures, control the inputs (Qadeer 2013; Rao 2009).

The so-called cure, or way forward, found in the majority of my policy sample, is to deliver more 'sustainable' mental health services. Gregory Marchildon (2013) problematises Canada's health funding, highlighting that since public budgeting rules require governments to carry capital expenditures as current liabilities, there is an incentive to reduce capital expenditures more than operating expenditures. The available healthcare funding itself in Canada has not enabled more sustainable mental health services for some time, as the number of psychologists or counsellors available has been well short of those who are categorised as needing such services worldwide, and this insufficiency has existed for a very long time (Albee 1968; Bruckner et al. 2011; Crowther and Ragusa 2011), not to mention for Indigenous peoples in Canada (Gone 2009). Gone (2003) further 
problematises the available mental health resources accessible to Indigenous peoples by labelling the production of psychologists as an 'infinite insufficiency', while saying that 'if mental health experts are willing to stipulate the conventional mental health services are essential for treatment of distress, (the number of psychologists) is so discordant that it recommends despair' (218). Indeed, as provinces call for more mental health services to be used by and available to Indigenous peoples, in practice the number of psychologists being trained in Canada has barely increased over the past 20 years (Marchildon 2013).

Here we see an inherent contradiction in the Canadian state's recommendation for mental health promotion. The market and production of psychologists is inadequate to meet the needs that state policies have created and promoted, for Indigenous and non-Indigenous peoples. Dennis Raphael et al. (2019) further criticise Canadian policy in general as containing:

profound levels of stratification, lack of decommodification, and the provision of minimal supports and benefits to Canadians ... enacting of public policies that benefit economic elites ... contribut(ing) to inequality, exploitation, exclusion, and domination of significant proportions of the citizenry. (21)

Similar to how Rachel Kirkland and Raphael (2018) criticise the utopian nature of health programmes in Canada, there is no result of the Canadian state improving the quality and distribution of health services. I also did not find this suggested in my policy sample. The state refers to Indigenous suicide as the result of psychology and social determinants, and yet the 'treatment' or 'solutions' that are inherently promoted by the state are not widely or sufficiently available to everyone. In addition, consider that the federal government completely controls and regulates the funding allocated to provinces (Canada Health Act 2020), leaving little to no room for private spending (Flood and Archibald 2001). The Canadian state has created a market of mental health resources and continues to contribute funds to it. Like Holmes' (2013) example of Mexican farm workers presented at the beginning of this section, structural violence towards marginalised populations is closely tied with market rule and capitalism, while the production of resources and the state is inadequate to support people. Under existing mental health service delivery conventions, available resources will seemingly never meet the 'mental health needs' of Indigenous peoples (Gone 2003).

\section{Economic Benefits}

On the colonial governance of the culturally Deaf, Harlan Lane (1999) posits that the market is controlled by hearing people. While the support available is supposedly conducted in the best interests of Deaf people, the benefits, or profits, go almost all of hearing people:

A hearing person entering one of the professions that serve Deaf people is expected to take on a way of perceiving and relating to Deaf people that operates to the social, psychological, and monetary advantage of hearing people. Moreover, the future of this very large audist establishment depends on the continuing desire of the hearing community to view culturally Deaf people as hearing impaired and to aim to mitigate this impairment as far as possible. Audists have the strongest inducement to believe that Deaf children and adults are indeed in need of hearing aids, sweet therapy, rehabilitation, and the like, and in need of hearing administrators to manage their affairs and to educate Deaf children. (Lane 1999: 49)

Who benefits economically from mental health services in Canada? The policies that I examined do not advocate for Indigenous health counsellors or professionals. Meanwhile, the funding that is being called for by these policies goes towards mental health services, or in other words, in the pockets of nonIndigenous peoples trying to make a career out of mental health. Thus, the promotion of mental health frameworks is self-serving to the Canadian state and non-Indigenous peoples. This promotion simultaneously reinforces Western mental health as the 'norm', reinforcing it as unchallengeable. The problem here lies within the complete lack of alternatives, or the freedom for alternatives to be included.

Suicide among Indigenous peoples in Canada, and the resources associated with 'fixing the problem', being conceived and controlled by the Canadian state, is clearly problematic. In my findings, policies attempted to obscure this by advocating for Indigenous leadership in suicide prevention programmes. On paper, this is a good idea; it has been argued that the most successful prevention programmes belong to and originate from the community itself (Kral 2012, 2019). Perhaps this is best explained by the idea that community members, friends, and family best understand the specific social context of the suicidal person (Wexler and Gone 2016). However, with closer inspection of the calls for Indigenous leadership in suicide prevention programmes, the language is fairly misleading. Increasing community control $^{7}$, improving support of community led action $^{8}$, meeting to discuss with Indigenous leaders ${ }^{9}$, 
acknowledging local knowledge ${ }^{10}$, and providing advice $^{11}$ is some of the language used in policies that try to convey that they will release control to Indigenous peoples. Interestingly, none of these examples suggest that communities nor Indigenous peoples will be able to fully create and manage their own programmes without state influence. The state controls funding, facilitates the implementation of approved programming, and pays lip service to Indigenous contributions but is seemingly reluctant to relinquish full control. Thus, the state sets parameters; Indigenous peoples are only able to act within the confines that they do not themselves determine.

Indigenous peoples are only able to act within state boundaries. They are able to seek health services that are ideologically supported by biomedicine and promoted by the state. The suicidal person's mental 'impairment' is created by the state in order to facilitate the sustainment of these services. Thus, the abnormality has been conceived by the state, while the state actively legitimises its own solutions. The individualistic nature of mental health services and social determinants reinforce settler-publics' perceptions of Indigenous peoples as incapable of self-governing and in turn legitimate ongoing, paternalistic state interventions as urgent and essential (Maxwell 2017). Because of this inequality of power, a moral authority is given to the Canadian state to intervene in the production of people's subjectivities. In Bruno Latour's (1984) terms, this moral authority is an energy that facilitates the existence and persistence of the entity that is the domination of people.

\section{Future Directions and Conclusion}

As I have tried to show in this article, suicide prevention policies perpetuate structural violence on Indigenous peoples in Canada in relation to suicide. These policies conceive suicide as an outcome of poor mental health, which is economically self-serving to the state. By positioning Indigenous suicide consistently through policy as a result of abnormal mental health, the state is able to largely avoid two things. First, the state distances itself from its own blame in Indigenous suicide. Current colonial policies that exist in Canada (Czyzewski 2011), such as those that allow the state to determine band membership and consequently remove the power from Indigenous peoples themselves are not referenced in Indigenous suicide consistently. Nor is past colonial actions or violence mentioned consistently. In this way, the Canadian state's own actions are not reflected upon. Secondly, the Canadian state is able to largely avoid the expensive route of Indigenous-led suicide prevention programmes. To fund economic and social repair among Indigenous communities (i.e., long-term funding for prevention programmes) is not targeted consistently in prevention policies. Research clearly shows that Indigenous-led programmes are more effective at reducing suicide (Kral 2019), but instead the target of policies is consistently on abnormal mental health; a potential symptom of not having access to long-term funding in the first place.

Furthermore, the Canadian state has ironically proven to be unable to provide remedies for the mental health problems that it has consistently identified in these policies. The state applies its own epistemology and ontology towards pseudosolutions to suicide prevention, resulting in a contradiction. By relying on individualised psychology, the state's ability and the general public's conception of larger social structures that could result in material change for Indigenous peoples and health outcomes is hindered. This would be in contrast to treating the created symptoms of abnormal psychology. Continuing with the irony, on a structural level, sustainable mental health services are non-existent for Indigenous peoples in Canada (Gone 2003, 2009; Marchildon 2009). We then have a situation where abnormal mental health, the most consistently identified factor in Indigenous suicide by the Canadian government, is simply unable to be addressed in its current state.

I suggest an overall improvement would come if cultural knowledge was not forced but accessible within any approach to suicide prevention. The room for engaging with contextualised healing practices may serve as a method of cultural continuity, allowing for an alignment between 'social, cultural, and political practices with the broader collective struggles for Indigenous autonomy and decolonization' (Radu 2018: 220). However, I have found little of this sentiment in my analysis of policy documents. There seems to be no alternative to Western psychology, while current prevention efforts typically rest at tailoring Western approaches to be "culturally appropriate'.

Scholars have advocated for Indigenous teachings related to holistic health to be incorporated, accepted, and promoted, to better understand and respond to the health of Indigenous people (Lavallee and Poole 2010). Growing research also shows that reconnection to Indigenous traditions, such as connection to territories, is a pathway to improving collective and individual Indigenous well-being (Henry et al. 2018; 
Kral 2019; Lambert 2018). However, recent decisions, such as one by the Canadian Supreme Court (Boynton and Zussman 2020) to reject opposition to a BC pipeline make 'connection to territories' look fairly unlikely.

For material efforts to even begin reconciling poor Indigenous health outcomes, such as suicide, that are in some way related to colonialism, policy makers, service providers, and researchers need to actively include traditional Indigenous knowledge in health models in their approaches (Waddell et al. 2017). However, based on my observations of the existing 'cultural appropriateness' in policies, there has been insufficient freedom for these local knowledges, traditions, and practices to be engaged with. By continuously falling back on Western mental health frameworks, Indigenous knowledge is peripheral; like the social sciences and humanities (Pedersen 2010), Indigenous knowledge is not currently seen as 'real science', nor is it sought for through by government-supported suicide prevention efforts (c.f. Aikenhead and Ogawa 2007; Dei 2000).

Here, I am not advocating for the complete erasure of mental health services, but more for the development of alternatives and choice. Mental health services are undoubtedly useful and beneficial to many Indigenous peoples in the world; however, I would speculate that programmes, conceptions, and approaches to Indigenous suicide (and any person's suicide for that manner) would be more effective if they had the conceptual malleability to adapt to contextual meanings, knowledges, and healing traditions of the people they serve. This thinking would more accurately and effectively suit the particularity of suicide.

Bryce Anderson is a PhD candidate at Dalhousie University, Canada. Bryce comes from a background in social anthropology and sociology. Bryce studies suicide, Durkheim, suicide prevention policy.

\section{Notes}

1. For example, Smith (2008) provides a lengthy operationalization of 'Western' and refers to the Western 'archive' of knowledge and systems (42). Smith defines this as what 'brings to bear, on any study of indigenous peoples, a cultural orientation, a set of values, a different conceptualization of such things as time, space and subjectivity, different and competing theories of knowledge, highly specialized forms of language and structures of power' (42).
2. By 'ideals of health and suicide' I am referring to conceptions such as what constitutes 'being healthy', the importance placed upon Western models of mental health such as the DSM, etc.

3. See Appendix 1 for a full list of materials examined.

4. Aboriginal Youth and Communities Empowerment Strategy (AYCES)

5. Final Report on the Evaluation of the Nunavut Suicide Prevention Strategy and Action Plan

6. INUUSIVUT ANNINAQTUQ Action Plan 20172022

7. Breaking Point: The Suicide Crisis in Indigenous Communities, Report of the Standing Committee on Indigenous and Northern Affairs

8. Inuusivut Anninaqtuq Action Plan 2017-2022

9. Reclaiming Hope: Manitoba's Youth Suicide Prevention Strategy

10. Changing Directions Changing Lives: The Mental Health Strategy for Canada

11. Saskatchewan First Nations Suicide Prevention Strategy

\section{References}

Aikenhead, G., and M. Ogawa (2007). 'Indigenous Knowledge and Science Revisited', Cultural Studies of Science Education 2, no. 3, 539-620.

Albee, G. W. (1968), 'Conceptual Models and Manpower Requirements in Psychology', American Psychologist 23, no. 5, 317-320.

Anderson, B. (2020), 'Colonial Sentiments: Examining Canadian Depictions of Indigenous Suicide', thesis manuscript, Dalhousie University.

Ansloos, J. (2017), The Medicine of Peace: Indigenous Youth Decolonizing Healing and Resisting Violence (Winnipeg: Fernwood Publishing).

Ansloos, J. (2018), 'Rethinking Indigenous Suicide', International Journal of Indigenous Health 13, no. 2, 8-28.

Bernard, H. (2018), Research Methods in Anthropology: Qualitative and Quantitative Approaches (6th ed.) (Lanham, MD: Rowman \& Littlefield).

Bernard, H., A. Wutich, and G. W. Ryan (2017), Analyzing Qualitative Data: Systematic Approaches (2nd ed.) (Thousand Oaks, CA: SAGE Publishing).

Boynton, S., and R. Zussman (2020), 'B. C. Government, Environmentalists "Disappointed" Over Trans Mountain Court Decision', Global News, https://globalnews.ca/news/6422611/bc-reaxtrans-mountain-pipeline-court-case/.

BREAKING POINT: THE SUICIDE CRISIS IN INDIGENOUS COMMUNITIES: Report of the Standing Committee on Indigenous and Northern Affairs (2017). Retrieved from: https://www.ourcommons 
.ca/Content/Committee/421/INAN/Reports/RP8977 643/inanrp09/inanrp09-e.pdf.

Bruckner, T., R. Scheffler, G. Shen, J. Yoon, D. Chisholm, J. Morris, and S. Saxena (2011), 'The Mental Health Workforce Gap in Low- and Middle-Income Countries: A Needs-Based Approach,' Bulletin of the World Health Organization 89, no. 3, 184-194.

Canada Health Act (2020). Retrieved from https://lawslois.justice.gc.ca/PDF/C-6.pdf.

Carstens, P. (2000), 'An Essay on Suicide and Disease in Canadian Indian Reserves: Bringing Durkheim Back In,' The Canadian Journal of Native Studies 20, no. 2, 309-345.

Chomsky, N., and M. Foucault (2006), 'Human Nature: Justice vs. Power', in The Chomsky-Foucault Debate on Human Nature (1-67) (New York: The New Press).

Crowther, J., and Ragusa, T. (2011), 'Realities of Mental Health Nursing Practice in Rural Australia', Issues in Mental Health Nursing 32, no. 8, 512-518.

Czyzewski, K. (2011). Colonialism as a Broader Social Determinant of Health. International Indigenous Policy Journal 2, no. 1, 1-14.

Dei, G. (2000), Rethinking the Role of Indigenous Knowledges in the Academy, International Journal of Inclusive Education 4, no. 2, 111-132.

Engler, Y. (2016), 'Owning the Media', in A Propaganda System: How Canada's Government, Corporations, Media and Academia Sell War and Exploitation, (120-152) (Winnipeg, Manitoba, Vancouver: Fernwood; RED Publishing).

Farmer, P. (2005), Pathologies of Power (California Series in Public Anthropology) (Berkeley: University of California Press).

Flood, C., and T. Archibald (2001), 'The Illegality of Private Health Care in Canada'. Canadian Medical Association. Journal 164, no. 6, 825-830.

Foucault, M. (2004), 'Chapter 11 (March 17, 1976)', in A. I. Davidson (Ed.) \& David Macey (Trans.), Society Must Be Defended: Lecture at the Collège de France, 1975-76 (239-264) (New York: Picador), http:// s3.amazonaws.com/arena-attachments/2288168/ a517f6153600c84ff334b416cf460745.pdf?1528579703.

Gone, J. P. (2003), 'American Indian Mental Health Service Delivery: Persistent Challenges and Future Prospects', in (eds.) J. S. Mio and G. Y. Iwamasa), Culturally Diverse Mental Health: The Challenges of Research and Resistance, (211-229) (New York: Brunner-Routledge).

Gone, J. P. (2009), 'Encountering Professional Psychology: Re-Envisioning Mental Health Services for Native North America', in (eds.) L. J. Kirmayer and G. G. Valaskakis, Healing Traditions: the Mental Health of Aboriginal Peoples in Canada (419-439) (Vancouver: UBC Press).
Henry, R., A. Lavallee, N. Van Styvendale, and R. A. Innes (2018), 'Introduction', in (eds.) R. Henry, A. LaVallee, N. Van Styvendale, and R. A. Innes, Global Indigenous Health: Reconciling the Past, Engaging the Present, Animating the Future, (3-24) (Tucson: University of Arizona Press).

Holmes, S. (2013), Fresh Fruit, Broken Bodies: Migrant Farmworkers in the United States (Berkeley: University of California Press).

Hyatt, S. B. (2005), 'Poverty in a "Post-Welfare" Landscape: Tenant Management Policies, Self-Governance and the Democratization of Knowledge in Great Britain', in (eds.) C. Shore and S. Wright, Anthropology of Policy: Critical Perspectives on governance and power, (166-182) (New York: Routledge).

Kirkland, R., and D. Raphael (2018), 'Perpetuating the Utopia of Health Behaviourism: A Case Study of the Canadian Men's Health Foundation's Don't Change Much Initiative', Soc Theory Health 16, no. 1: 1-19.

Kral, M. J. (2012), 'Postcolonial Suicide Among Inuit in Arctic Canada', Culture, Medicine and Psychiatry 36, no. 2, 306-325.

Kral, M. J. (2019), The Return of the Sun: Suicide and Reclamation Among Inuit of Arctic Canada. Advances in Community Psychology (New York: Oxford University Press).

Lambert, S. (2018), 'Introduced Biotechnologies, Traditional Lands, and Indigenous Well-Being: The Expanding Assemblage of Small-Scale Maeori Horticulture Through the "Indigenous Turn",' in (eds.) R. Henry, A. LaVallee, N. Van Styvendale, and R. A. Innes, Global Indigenous Health: Reconciling the Past, Engaging the Present, Animating the Future (99-118) (Tucson: University of Arizona Press).

Lane, H. (1999), The Mask of Benevolence: Disabling the Deaf Community (new ed.) (San Diego: DawnSignPress).

Latour, B. (1984), 'The Powers of Association', The Sociological Review 32, no. 1, 264-280.

Lavallee, L.F., and J. M. Poole (2010), 'Beyond Recovery: Colonization, Health and Healing for Indigenous People in Canada', International Journal of Mental Health Addiction 8, no. 2, 271-281.

Leenaars, A. A. (2006), 'Suicide Among Indigenous Peoples: Introduction and Call to Action', Archives of Suicide Research 10, no. 2: 103-115.

Macklem, P. (1991). 'First Nations Self-Government and the Borders of the Canadian Legal Imagination', McGill Law Journal 46, no. 2: 382-456.

Marchildon, G. (2013), Health Systems in Transition: Canada (Toronto: University of Toronto Press).

Maxwell, K. (2017), Settler-Humanitarianism: Healing the Indigenous Child-Victim', Comparative Studies in Society and History 59, no. 4, 974-1007. 
Murphy, F. (2011), 'Archives of Sorrow: An Exploration of Australia's Stolen Generations and their Journey into the Past', History and Anthropology: The Political Lives of Documents 22, no. 4: 481-495.

National Aboriginal Youth Suicide Prevention Strategy (NAYSPS) (2013). Retrieved from: https://www .canada.ca/content/dam/hc-sc/migration/hc-sc/fniahspnia/alt_formats/pdf/pubs/promotion/_suicide/ strat-prev-youth-jeunes-eng.pdf

Nelson, S., and K. Wilson (2017), 'The Mental Health of Indigenous Peoples in Canada: A Critical Review of Research', Social Science \& Medicine 176: 93-112.

Pedersen, R. (2010), 'Empathy development in medical education-A critical review', Medical Teacher 32, no. 7: 593-600.

Powell, A. and C. Gabel (2018), 'Addressing Inequalities: Understanding Indigenous Health Policy in Urban Ontario, Canada', in (eds.) R. Henry, A. LaVallee, N. Van Styvendale, and R. A. Innes, Global Indigenous Health: Reconciling the Past, Engaging the Present, Animating the Future (237-256) (Tucson: University of Arizona Press).

Qadeer, I. (2013), 'Universal Health Care: The Trojan Horse of Neoliberal Policies', Social Change 43, no. 2: 149-164.

Radu, I. (2018), 'Uschiniichisuu Futures: Healing, Empowerment, and Agency Among the Chisasibi Cree Youth', in (eds.) R. Henry, A. LaVallee, N. Van Styvendale, and R. A. Innes, Global Indigenous Health: Reconciling the Past, Engaging the Present, Animating the Future (211-234) (Tucson: University of Arizona Press).

Rao, M. (2009), 'Health For All' And Neoliberal Globalisation: An Indian Rope Trick', in (eds.) L. Panitch and C. Leys, Morbid Symptoms: Health Under Capitalism (262-278) (London: The Merlin Press).

Raphael, D., M. Komakech, T. Bryant, and R. Torrence (2019). 'Governmental Illegitimacy and Incompetency in Canada and Other Liberal Nations: Implications for Health'. International Journal of Health Services 49, no. 1: 17-36.

Saskatchewan First Nations Suicide Prevention Strategy (2018). Retrieved from: https://www.suicideinfo .ca/wp-content/uploads/gravity_forms/6-191a85f36 ce9e20de2e2fa3869197735/2018/07/SaskatchewanFirst-Nations-Suicide-Prevention-Strategy_oa.pdf

Scheper-Hughes, N. (1992). Death Without Weeping: The Violence of Everyday Life in Brazil (Berkeley: University of California Press).

Shore, C. and S. Wright (2005), 'A New Field of Anthropology', in (eds.) C. Shore and S. Wright, Anthropology of Policy: Critical Perspectives on governance and power (3-30) (New York: Routledge).

Smith, L. T. (2008). Decolonizing Methodologies (New York: Zed Books). Retrieved from: https://nycstandswithstandingrock.files.wordpress.com/2016/10/ linda-tuhiwai-smith-decolonizing-methodologiesresearch-and-indigenous-peoples.pdf.

Staples, J. (2016). 'Personhood, Agency and Suicide in a Neo-Liberalizing South India', in (eds.) D. Münster and L. Broz, Suicide and Agency: Anthropological Perspectives on Self-Destruction, Personhood, and Power (27-45) (New York: Routledge).

Targum, S. D., and J. Kitanaka (2012), 'Overwork Suicide in Japan: A National Crisis', Innovations in Clinical Neuroscience 9, no. 2: 35-38.

The Federal Framework for Suicide Prevention (2016). Retrieved from: https://www.canada.ca/content/ dam/hc-sc/documents/services/publications/healthyliving/64-03-18-2232-ProgressReport-SuicidePrevention_EN-06-eng.pdf

Waddell, C., R. Robinson, and A. Crawford (2017), 'Decolonizing Approaches to Inuit Community Wellness: Conversations with Elders in a Nunavut Community', Canadian Journal of Community Mental Health 36, no. 1: 1-13.

Wexler, L. M., and J. P. Gone (2016), 'Exploring Possibilities for Indigenous Suicide Prevention: Responding to Cultural Understanding and Practices', in (eds.) J. White, I. Marsh, M. J. Kral, and J. Morris, Critical Suicidology: Transforming Suicide Research and Prevention for the 21st Century (56-70) (Vancouver: UBC Press).

White, J. (2017), 'What Can Critical Suicidology Do?', Death Studies 41, no. 8: 472-480. 


\section{Appendix 1: Suicide Prevention Policies, Reports, and Statutes Examined}

\begin{tabular}{l} 
Name \\
\hline An Act Respecting a Federal \\
Framework for Suicide Prevention \\
Breaking Point: The Suicide Crisis in \\
Indigenous Communities (House of \\
Commons) \\
Changing Directions, Changing Lives: \\
The Mental Health Strategy for Canada \\
Connecting to Life: Provincial Suicide \\
Prevention Program (NB) \\
Final Report on the Evaluation of the \\
Nunavut Suicide Prevention Strategy \\
and Action Plan \\
Honouring Life: Aboriginal Youth and \\
Communities Empowerment Strategy \\
(AYCES)
\end{tabular}

Honouring the Truth, Reconciling for the Future

Indigenous Suicide Prevention: Centre for Suicide Prevention

INUUSIVUT ANNINAQTUQ Action Plan 2017-2022

National Aboriginal Youth Suicide Prevention Strategy (NAYSPS) Program Framework

National Inuit Suicide Prevention Strategy

Nova Scotia Strategic Framework to Address Suicide

Nunavut Suicide Prevention Strategy

Ontario's Youth Suicide Prevention Plan

Overview of Federal Initiatives in Suicide 2016 Prevention

Resiliency Within: An Action Plan for Suicide Prevention in Nunavut 2016/2017

Roots of Hope: A Community Suicide Prevention Project
Year Link

Written

2012 https://laws-lois.justice.gc.ca/PDF/2012_30.pdf

2017 https://www.ourcommons.ca/Content/Committee/421/ INAN/Reports/RP8977643/inanrp09/inanrp09-e.pdf

2012 https://www.mentalhealthcommission.ca/sites/default/ files/MHStrategy_Strategy_ENG_0_1.pdf

2007 https://www.gnb.ca/0055/pdf/4768e-compressed.pdf

2015 https://nspsummit.ca/sites/default/files/NSPS\%20Evalua tion\%20FINAL\%20Report\%20June\%202015.pdf

2009 https://www.albertahealthservices.ca/assets/healthinfo/ MentalHealthWellness/hi-mhw-honouring-life-final.pdf

2015 http://www.trc.ca/assets/pdf/Honouring_the_Truth_ Reconciling_for_the_Future_July_23_2015.pdf

n.d. https://www.suicideinfo.ca/resource/indigenoussuicide-prevention/

2017 https://www.gov.nu.ca/sites/default/files/inuusivut_ann inaqtuq_english.pdf

2019 https://www.canada.ca/content/dam/hc-sc/migration/ hc-sc/fniah-spnia/alt_formats/pdf/pubs/promotion/ _suicide/strat-prev-youth-jeunes-eng.pdf

2016 https://www.itk.ca/wp-content/uploads/2016/07/ITKNational-Inuit-Suicide-Prevention-Strategy-2016.pdf

2006 https://novascotia.ca/dhw/healthy-communities/docu ments/Nova-Scotia-Strategic-Framework-to-AddressSuicide.pdf

2010 https://www.gov.nu.ca/sites/default/files/files/NSPS_ final_English_Oct\%202010(1).pdf

2016 http://www.children.gov.on.ca/htdocs/English/profes sionals/specialneeds/suicideprevention.aspx

https://healthycanadians.gc.ca/publications/healthyliving-vie-saine/mental-health-sante-mentale/overviewsuicide-apercu-matiere-suicide/alt/ofisp-aifmps-eng.pdf

2016 https://www.gov.nu.ca/sites/default/files/resiliency_ within_eng.pdf

2019 https://www.mentalhealthcommission.ca/English/ roots-hope 


\begin{tabular}{lll}
\hline Name & Year & Link \\
& Written & \\
\hline
\end{tabular}

Reclaiming Hope: Manitoba's Youth n.d. https://www.gov.mb.ca/health/mh/docs/hope.pdf

Suicide Prevention Strategy

Saskatchewan First Nations Suicide

Prevention Strategy

2018 https://www.suicideinfo.ca/wp-content/uploads/gravity _forms/6-191a85f36ce9e20de2e2fa3869197735/2018/07/

Saskatchewan-First-Nations-Suicide-Prevention-Strat egy_oa.pdf

The CASP Blueprint for a Canadian

2009 https://suicideprevention.ca/resources/Documents/ National Suicide Prevention Strategy SuicidePreventionBlueprint0909.pdf

The Federal Framework for Suicide Prevention-Progress Report 2018

2018 https://www.canada.ca/content/dam/hc-sc/documents/ services/publications/healthy-living/64-03-18-2232-Pro gressReport-SuicidePrevention_EN-06-eng.pdf

The Federal Framework for Suicide

2016 https://www.canada.ca/content/dam/canada/publicPrevention health/migration/publications/healthy-living-vie-saine/ framework-suicide-cadre-suicide/alt/framework-sui cide-cadre-suicide-eng.pdf 